\title{
Shakespeare was indisputably an accountant!
}

Shakespeare was indisputably an accountant!

\section{Introduction}

In spite of the tomes written about William Shakespeare over the centuries, it is clear to the author of this paper that one of the Bard's most obvious areas of knowledge has been overlooked by academics and critics: Shakespeare was an accountant! Shakespeare was fascinated by money, profit and property: his characters earn it, lose it, risk it, increase it, marry for it, kill in its pursuit, count it repeatedly, secrete it, record it in columns, use it to gain power or to control Kings and even, at times, forget they are mere mortals because of its allure.

Looking at this emphasis on money makes it clear that our playwright often ignored the maxim "Cupiditas radix malorum est[1]" in order to serve his Muse as he laughs at human folly in the comedies and grieves at human fallibility in the tragedies: we shall even have a brief look at two histories. Money and assets and their power are in all of them.

Shakespeare himself, of course, amassed a tidy sum during his lifetime, acquiring fame and favor in the theatres of London and at Court, and spending his gentrified last months in the fashionable New Place in his beloved Stratford[2]. His hard-working wife, as we read in Germaine Greer's "Shakespeare's Wife," ably stewarded and ran his business interests and their village home while he was in the capital building fame and fortune, enjoying other pleasures[3]. But women and love are not the subject of this paper... except when women and money unite their power!

The author has shamelessly borrowed from Polonius in "Hamlet" to provide a framework for this paper. On the arrival of the Players at Elsinore, and in an attempt to please Queen Gertrude and to placate King Claudius by distracting Hamlet from his despair over his father's death, Polonius tells the Prince that these actors are adept in the popular theatrical genre of the day:

The best actors in the world, either for tragedy, comedy, history, pastoral, pastoral- comical, historical-pastoral, tragical historical, tragical-comical-historical-pastoral, scene individable, or poem unlimited. (Arden Shakespeare, Jenkins, 1982, page 59)

This paper presents a discussion of Shakespeare's fascination with accounting, stewardship and property, structured around the theatrical categories outlined by Polonius. Section 1 introduces this paper's theme. Section 2 deals with two tragedies; Section 3 deals with two histories; Section 4 introduces argument based on two comedies; and Section 5 discusses a play of mixed genre. Shakespeare's poems are not included.

\section{The tragedies}

\section{1 "Hamlet"}

Let us begin then with Polonius who, although garrulous and self-seeking, has a clever business mind and has won the favor of both King Claudius and Queen Gertrude and has risen through the ranks at Court. His focus on money and profit is clear when, early in the play, he questions Ophelia about her relationship with Hamlet: there is no paternal concern for her feelings but he places heavy emphasis on business, using expressions like, "Do you believe his tenders, as you call them?" (page 204 Arden series, edited by Jenkins, 1982); "[...] you have ta'en these tenders for true pay which are not sterling" (Jenkins, 1982, p. 205); and "set your entreatments at a higher rate [...]" (Jenkins, 1982, p. 206) (emphasis added).

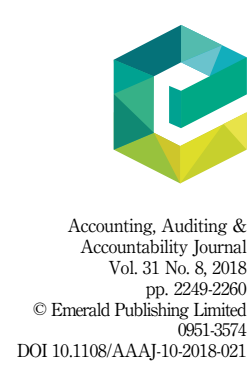


AAAJ 31,8
This is puzzling terminology when discussing love but the Polonius-world is clearly seen: he recognizes the material worth of his daughter. His focus is on profit in that her youth and beauty, since Hamlet is the Prince of Denmark and the darling of his mother the Queen, add to a financial opportunity, equal enhanced status, property and wealth. We see that Ophelia is a valuable asset, crucial to her father's estate.

Polonius' knowledge of the power of money is also seen in his employing Reynaldo to spy on his son, Laertes, who has returned to his studies in France. His instructions focus on money: "Give him this money and these notes Reynaldo" (Arden Shakespeare, Jenkins, 1982, p. 229); "Inquire me first what Danskers are in Paris [...] what company; at what expense [...]" (Arden Shakespeare, Jenkins, 1982, p. 229); and Polonius' reference to Laertes visiting a brothel "I saw him enter such a house of sale-videlicet a brothel" (Arden Shakespeare, Jenkins, 1982, p. 232), and are later summed up in Polonius' own credo that he will, "By indirections find directions out" (Abbey Library, 1969, p. 855). Of course, this echoes his knowledge of Ophelia's movements.

"He" is Prince Hamlet, and the innuendo behind "told" is reward for services rendered: the balance sheet is clearly in Polonius' mind but he lacks the depth and vision of the professional accountant. Value to Polonius is opportunistic action and personal financial gain.

The master spies, Hamlet's friends from boyhood, Rosencrantz and Guildenstern, are employed to discover the cause of Hamlet's "madness" and Gertrude openly promises money: "Your visitation shall receive such thanks as fits a King's remembrance" (Arden Shakespeare, Jenkins, 1982, p. 237, lines 25-26). These self-seeking fools succumb to the persuasive power of profit, selling loyalty and services to the King but sacrificing the professional honor of those who serve with excellence. The focus on ethical leadership emphasized in the codes of corporate governance resonates here. The King (Claudius), corrupted by ambition and desire, controls corrupt men because he himself lacks integrity.

Of course, Hamlet is too clever to be deceived by Rosencrantz and Guildenstern, whose deaths he later orchestrates, and Polonius is killed by Hamlet while himself trying to further his greedy plans by spying on Gertrude and Hamlet for Claudius. In 2017, corruption is still severely stigmatized and/or even punished by strict codes of governance because whatever promotes selfinterest is not ethical leadership. If the function of the auditor is to, at least, attest to the veracity of the report, Polonius needed an auditor to assure balance, not a solitary focus on greed!

The final irony in this much-loved play is that the poison intended to kill Hamlet if the deception of Laertes fails in the duel is secreted inside a pearl of great value. Claudius, now desperate to rid himself of the Prince and to retain the queen and kingdom he killed his brother and damned himself for, says:

The King shall drink to Hamlet's breath, and in the cup an union shall he throw richer than that which four successive Kings in Denmark's crown have worn [...]. (Arden series, Jenkins, p. 41, lines 269-270)

In her thirst, Gertrude drinks from the goblet intended for her son and dies in agony as she warns him. Shakespeare, the accountant, is tracing risks and the lack of risk management when corrupt practice and procedures are allowed.

As the poison on Laertes' blade begins its deadly work, Hamlet forces the last of the wine down Claudius' throat, saying:

Drink off this potion. Is thy union here? (Arden series, Jenkins, page 414, line 331)

His own death follows.

\section{2 "Macbeth"}

A play favored by audiences through the ages, in spite of its reputation for bringing bad luck to performers and backstage crews, remains "Macbeth." Of course, a familiar world 
emerges here: a world of war and valor, loyalty and betrayal, fathers and their children, husbands and wives, and, again, wealth and its accompanying desire for power and retaining such power, even at the cost of love, life and the soul.

Let us consider who the accountants and/or stewards are in this cast of characters.

Duncan, King of Scotland, as the medieval link between God and man, impresses by not allowing his strong emotions to cloud his Kingly decisions. It is a simple matter of debit and credit after all: the treacherous Thane of Cawdor, who has raised his sword against King and country, will die, while the valorous and favored Macbeth, Thane of Glamis, will be given the added title Thane of Cawdor.

The kudos accompanying the title is unquestioned but so are the castle, the ancestral lands, the wild and the domesticated animals on those lands, the servants and, above all, the peasants who provide labor and taxes in times of peace and a private army in times of war. This is clearly an example of sophisticated accounting[4].

Paul Zweig ("The Heresy of self-love," p. 67):

During the eleventh century the older ranks of the nobility had found a way to enforce their military strength by conferring knighthood, along with fiefs, on many I of their retainers. In return, ennobled vassals owed military service to their benefactors, as did the vassals who were given [new] titles [...].

Macbeth himself also closely links power and monetary value: he employs a number of images, describing his reputation as "Golden opinions from all sorts of people" (Arden series, edited by Kenneth Muir, 1989, p. 40). Later while planning Banquo's murder, horrified at his own damnation, he describes his soul now lost by murdering Duncan "as mine eternal jewel" (Muir, 1989, p. 75).

After killing Duncan, he equivocates as is his manner (this is his tragic flaw), professing his "loyalty" to the King he has just murdered, as he describes Duncan's corpse figuratively as precious metals:

His silver skin lac'd with his golden blood. (Arden Shakespeare, Ed., Muir, 1989, p. 66)

Clearly, there is a finance/accounting mind at work here, an emphasis on the mining industry. The final image in this vein belongs to Macduff: after he has rightfully vanquished "the tyrant," Macbeth, in combat, he proclaims Malcolm's[5] reign by saying:

[...] the time is free. I see thee compass'd with thy Kingdom's pearl. (Arden Shakespeare, Ed., Muir, 1989, p. 162)

Here, Macduff acknowledges the contribution of Malcolm's loyal Thanes, major stakeholders in the future of Scotland. Malcolm, in turn, promises promotions and rewards, clearly indicating that he understands the importance of different kinds of capital, including human, natural, financial and equipment. All of these reflect the aims of the modern integrated report (paraphrase of point from King, Code III, 2009).

This indicates Shakespeare's fascination with the frightening power of money and the obvious need for financial experts to be in charge of it! Financial transactions are supposed to be principles based and also linked to innovative management (paraphrase of King, Code III, 2009). The author surmises that Shakespeare would have added themes like goodwill, materiality and off balance sheet issues to his plays had he still been writing in 2017 .

\section{The histories}

3.1 "Julius Caesar"

Roman rule meant constant maintaining and curating. This demanded great fortunes and manpower: wars needed to be financed; spoils and slaves to be taken; looting and pillaging controlled; loyal troops rewarded; the value of land assessed; allotments granted. Financial experts had to make sure the coffers of Rome and the victorious generals and their allies were full. 
AAAJ 31,8
This meant debts and keeping records at the whim of the Senate (Republic) and Emperors (Empire) in turn. Money and those accountable for it kept the ancient world turning[6]. In Cassell's New Latin Dictionary, "scriba" is defined as, "a clerk, secretary or notary in the service of the Senate or magistrates" (Cassell, 1966, p. 539) and "quaestores" is defined as the officials who fulfilled a range of important duties, one being "in charge of the State treasury" or "accompanied consuls on military campaigns [...] and acted as paymasters" (Cassell's New Latin Dictionary, 1966, p. 492). It becomes clear that profit, payments and paymasters were of great importance.

In "Julius Caesar" Act I, Flavius, later executed for dishonoring Caesar's statues, recognizing the fickleness and crassness of the mob says:

These growing feathers pluck'd from Caesar's wing will make him fly an ordinary patch. (Arden Shakespeare, Dorsch, 1966, p. 7)

Flavius knows how easy it is to buy the mob's loyalty: they had loved Caesar's vanquished ally/enemy, Pompey (74 - 63 B.C.) but had switched allegiance to Caesar who was persuasive, generous and politically and financially astute.

Caesar's military triumphs, campaigns recorded in "De bello Gallico VI" (Julius Caesar, Ed., Colbeck, 1963, p. 1-29) and throughout the following centuries by the legions of historians, pay homage to the great Dictator but do not account for the financial costs, the raising of capital, fines, plunder. For that the accountants were responsible: Shakespeare takes cognizance of this. The huge crowds following Caesar, for example, on the morning of his death, show the power of money, games and free bread, as does the multitude gathered to have the "assassination" explained at Caesar's funeral.

Of course, the bread and entertainment were not free but the astute financial management by government and powerful wealthy men made the placating of the urban mob possible. The "cursus honorum" (hierarchy of office) had clearly defined work to complete, each "employee" (official) aware of this: they were guided and rewarded by educated men unwilling to surrender their status and influence through risk. We are reminded here of King's repeated call for effective leadership based on ethical foundation (paraphrased from King, Code III, 2009).

During the funeral, the terror and shock are at first allayed by Brutus' idealistic political speech in which the emphasis is on "honor" and "wisdom" (Arden Shakespeare, Dorsch, 1966, p. 79). The mob immediately swings to Brutus' side:

- "Let him be Caesar" and another citizen delivers these sinister lines as Antony enters, accompanying Caesar's corpse;

- "What does he say of Brutus?"; and

- “Twere best he speak no harm of Brutus here!" (Arden Shakespeare, Ed., Dorsch, 1966, p. 80).

Antony sways the mob in an even shorter time: he recognizes the citizens of Rome as significant capital. He is a consummate performer but, above all, he is a shrewd accountant. If we ignore the personal loyalty and anger expressed, we find an exceptional integrated report which not only presents data but also deals with corporate responsibility and transparency. In simple terms, the numbers work: "This is what he has given you and this is what you owe him" (Author's comment but the implication is Shakespeare's). Under responsible leadership, all shareholders will benefit. The ignorance and gullibility of the mob are completely opposite to Antony's logical planning. The author suggests that Rome and her vast territories can be seen as the company, Caesar as the CEO and the citizens as the shareholders.

Antony carefully selects what he includes in his report to the mob. He reminds the citizens that Caesar "hath brought many captives home to Rome/whose ransoms did the general/coffers fill [...]" (Arden Shakespeare, Ed., Dorsch, 1966, p. 81). Ah, yes, all would have known that full coffers equaled bread and games for the public[7]. 
He further informs the mob that Caesar's heart belonged to the poor:

When that the poor have cried, Caesar hath wept [...]. (Arden Shakespeare, Ed., Dorsch, 1966, p. 81)

Then, in a masterstroke of political and financial prowess, he refers to Caesar's will and to the clause which names the citizenry as his heirs:

Tis good you know not that you are his heirs; For if you should, o, what would come of it? (Arden Shakespeare, Ed., Dorsch, 1966, p. 81)

The liaison of money and power fascinates us still: predictably, in this play, the result is a bloody civil war and, after the Battle of Actium and the suicide of Antony himself (31 B.C.), the end of the Roman Republic. This "new" beginning provides the opportunity for future research. As the Empire began, many of the structures of state remained and many proven processes were followed. Cary and Haarhoff (1966, "Life and thought in the Greek and Roman world," p. 79) tell us that the Emperor Augustus employed "a staff of financial commissioners" and "a secretariat [...] of accountants [who] drew up his departmental budget” (p. 79).

\subsection{King Henry $\nabla$}

As we continue to borrow Polonius' framework, let us, in true Shakespearian style, move forward some centuries and many kilometers to the England of Henry $\nabla$. Our theme remains the same: the accountant, or the cofferer as he would then have been named (de Lisle, 2013, p. 247). Ah, we pity and envy these gentlemen who often achieved wealth and property but who had to balance the accounts of Church and State while pleasing monarchs and clergy. Money is again the means, as well as the end.

The author is not crudely suggesting as did Richard Rich who rose to power under Cromwell, successor to the once hugely wealthy and influential Cardinal Wolsey who lost the favor of Henry VIII, that "every man has his price! [...] But yes! In money too [...]" (Bolt, 1985, p. 2) but it is clear that much money to fund foreign wars, as against France in "King Henry $\nabla$," came from the Church: the marriage of wealth and power is clear throughout this play. The Archbishop of Canterbury himself in the first scene announces:

For I have made an offer to his majesty, Upon our spiritual convocation, And in regard of causes now in hand, Which I have spen'd to his grace at large, As touching France, to give a greater sum Than ever at one time the clergy yet Did to his predecessors part withal. (Arden Shakespeare,

Ed., Walter, 1985, p. 12) (emphasis added)

The matter described above as "touching France" is the throne of France itself, the possibility of that sovereign power through Henry $\nabla$ 's maternal bloodline but the foundation is the accountants responsible to all those paying and to those spending: it is clear that such men are by any name, accounting and accountable[8].

As in the comedies and tragedies, high-born wives are of great monetary and political value: before Henry's victorious siege at Harfleur, the French ambassador, "Tells Harry that the king doth offer him Katharine his daughter; and with her, to dowry, some petty and unprofitable dukedoms" (Arden Shakespeare, Walter, 1985, p. 57).

The offer is rejected out of hand! Saddened also by the earlier treason of Cambridge, Grey and Scroop, "for a few light crowns" (Arden Shakespeare, Walter, 1985, p. 41), "for the gold of France" (Arden Shakespeare, Walter, 1985, p. 85), Henry seeks no personal revenge but commits these once-trusted advisors to the laws of England: a tragic outcome indeed, but a good example of the need for ethical leadership (King, Code III, 2009).

After Agincourt, in spite of losses, Henry's "poor and starved band" are victorious (Arden Shakespeare, Walter, 1985, p. 107). Granpre's finance-image before the battle, 
AAAJ 31,8

"Big Mars seems bankrupt in their beggar'd host" (Arden Shakespeare, Walter, 1985, p. 109) is only empty words: the numbers are counted, the totals are presented: Henry announces:

"This note doth tell me of ten thousand French that in the field lie slain", only "sixteen hundred [of whom were] mercenaries" (Arden Shakespeare, Walter, 1985, p. 134). The English dead, including four men of high rank and property, is twenty-nine in total. God is given the praise but the accountants have raised the finance.

Was ever known so great and little loss on one part and on the other? (Arden Shakespeare, Walter, 1985, p. 134)

Historically, we learn that the marriage of Henry to Princess Katherine was a happy one but it was nevertheless carefully brokered and is based on a military, political and financial union between England and France: heirs, manpower in times of war and abundant taxes are a noteworthy profit. Henry's proposal makes this clear:

England is thine, Ireland is thine, France is thine and Henry Plantagenet is thine. (Arden Shakespeare, Walter, 1985, p. 151)

The King of France agrees to every clause, "His daughter first" (Arden Shakespeare, Walter, 1985, p. 154), securing some years of peace and prosperity, honoring the united debt to Church and taxpayers[9].

Even later in the 1500s of Henry VIII, powerful and corrupt men like Cardinal Wolsey and Thomas Cromwell rose to and fell from favor because of neglecting accounting in line with the Monarch's desires and needs[10]. This is rich material for further research.

\section{The comedies}

\section{1 "A midsummer night's dream"}

By convention, the Classical comedy ends in marriage while the Classical tragedy ends in death (the author is consciously overlooking the fact that many people see a similarity between marriage and death). All the same, in many of the comedies, potentially tragic, and disturbing, events occur.

This is so in the well-loved "A midsummer night's dream" which looks closely at power relationships[...] and most of this influence is, again, vested in money, the status it bestows and who accounts for it. The foremost power relationship is between Theseus, the Duke and Hippolyta, queen of the Amazons, who wait for the passing of "four happy days" until they marry (Arden Shakespeare, Brooks, 1983, p. 5). Theseus immediately makes it clear that she is a great prize but that he holds more power and property than she:

Hippolyta, I woo'd thee with my sword, And won thy love doing thee injuries. (Arden Shakespeare, Brooks, 1983, p. 7)

If any accountant reading this is wondering how a duke can have more power than a queen, it is explained simply by Maureen Duffy ("The erotic world of faery," p. 154) as Theseus being "a dux or military leader." This reflects closely the professional hierarchy of leadership in firms today, reflected in titles, responsibilities and influence.

Oberon, King of the Fairies, echoes these power politics in the woods outside Athens when he encounters Titania, his queen and wife:

Tarry, rash wanton; am I not thy lord? (Arden Shakespeare, Brooks, 1983, p. 30)

Do you amend it then [...] why should Titania cross her Oberon? (Arden Shakespeare, Brooks, 1983, p. 35)

The play also introduces the theme of father-daughter relationships, iterating the idea that a daughter is the property of her father. Some fathers in Shakespeare are responsible and 
honorable stewards[11] but here Egeus shocks everyone when (because Hermia refuses to marry the man of his choice, Demetrius) he begs from Theseus:

[...] the ancient privilege of Athens, As she is mine, I may dispose of her; Which shall be either to this gentlemen, Or to her death [...]. (Arden Shakespeare, Brooks, 1983, p. 8)

Shakespeare

was

indisputably an accountant!

The "dispose of" is deeply disturbing and suggests that Hermia is an object and a disposable resource. The accountant will immediately see that no resource is infinite and so a respectful, thoughtful and planned response is paramount. Mervyn King focuses on integrity and ethics (emphasis added). (King, Code III, 2009). Egeus ignores all of these, acting unethically and with potentially disastrous consequences.

Of course, confusion and danger explode on all sides and complex subplots emerge before the denouement. After mistakes amusing and frightening, and the involvement of the faeire world, as Theseus' wedding day dawns in the woods outside Athens, the Duke finally overrules the tyrant-father:

Egeus, I will overbear your will; For in the temple, by and by, with us, These couples shall eternally be knit. (Arden Shakespeare, Brooks, 1983, p. 97)

Imagine the complex accounting facing those employed to draw up and calculate these marriage contracts. Where does the accountant's work end and the lawyer's begin[...] is this social or corporate responsibility? The author wonders if there will be a King V or VI in an attempt to demystify such issues.

Money, value, land and assets remain constant themes as the King and Queen of the faeries continue to fight each other's stubborn demands and so disrupt the very balance of nature which is seen at this point to be ill, producing floods, contagion and rotten crops. This reminds us today of global warming, deforestation, over-fishing, toxic water and King's call for ethical leadership and corporate responsibility.

Oberon demands once more the little Indian changeling who is the cause of their disagreement. Titania replies:

"The fairy land buys not the child of me" (Arden Shakespeare, Brooks, 1983, p. 35). So much for

love: financial wrangling and material value win!

Titania and Oberon ignore procedure and process, allowing ego and emotion to cloud their thinking. He feels that, as King of the faeries (CEO), his judgments are principal; she feels that, because the boy's mother was her own loving and beloved follower, she must honor her promise to "rear up [the] boy" (Arden Shakespeare, Brooks, 1983, p. 36) after the mortal mother's death.

Perhaps, the author humbly suggests, the fascinating royal couple should consider handing the royal "firm," as Queen Elizabeth II is quoted in the media as having quipped about the current royal family, to the Board, the auditors and the accountants. Accounting has its origins in the need to "keep account." This may ensure the integrity of reporting, more effort in the detection of misdemeanor, a reliable basis for assessing leadership, etc., but there is little structure in the world of faeries because Oberon has control but no skills to manage resources.

Titania is later "tamed" by magic but Shakespeare has once again emphasized the importance of accountants and stewards if collapse and extreme measures are to be avoided. As already indicated, the author defers the discussion of women and money for future research and the Faerie Queen is certainly worth further consideration. As Maureen Duffy succinctly states, "Titania was Elizabeth[12]" ("The erotic world of faery," p. 152).

\section{2 "Twelfth night"}

There are no faeries in "Twelfth Night," of course, but there are fools aplenty: Shakespeare VIII mercilessly mocks human folly, much of the satire being aimed at infatuation, gullibility 
AAAJ 31,8 and, again, attitudes to money and assets, both in those who have wealth and those who lack it.

Let us consider who the accountants and/or stewards are in this fascinating cast of characters, as we did in "Macbeth" (Section 2.2).

The Countess Olivia herself "richly left" (if the author may borrow from "The merchant of Venice" (discussed in Section 4) is angry about her uncle's inappropriate behavior, namely, drunkenness, riotousness and idleness. The lady herself obviously obeys the rules of moderation as she manages both her estate and her conduct: only Sir Toby Belch (the author's most beloved name in all of the Bard's work, if she may for a moment digress) does not agree to management as a process. Sir Toby has his own financial accounting strategy: befriend a vain fool who is extremely rich and minimally intelligent, and this equals a solid income, gallons of ale and no work. When questioned about his ally, Sir Andrew Aguecheek (the author's second favorite name in all of Shakespeare), Toby impatiently explains that Andrew is there merely because:

[...] he has three thousand ducats[13] a year. (Arden Shakespeare, Ed., Lothian and Craik, p. 12) and so, according to Toby's accounts, no other talents or skills or morals are necessary.

Is this the Renaissance version of the beginning of the economic collapse we all know so well in the twenty-first century or is Sir Toby just a boastful rogue accountant, exploiting the lack of explicit professional guidelines? Sir Toby, and Olivia's steward, Malvolio, break the rules so let us remind ourselves here of Shakespeare's fascination with accounting and accountability (or the absence of both). The attest function of the accountant/auditor is to make sure that the figures and reports are honest and correct: this applies to private accounts, corporate, national and international. The University of the Witwatersrand (SAKAI, 2017) emphasizes that:

Students need to appreciate that they are [part of a group] based on the highest standards of [...] competency and ethics.

Too little regulation (Malvolio) and too much regulation, or an attempt at this (Sir Toby), are equally counter effective.

We are not discussing in this paper the mistaken identities, foolish infatuations or potentially dangerous situations which shape the plot but shall conclude our comedy section with a closer look at the Countess Olivia's steward, Malvolio.

The concept of stewardship has been universally acknowledged for centuries and has even gained kudos in recent years as corporate social responsibility and integrated reports have moved into the spotlight.

According to the New Shorter Oxford Dictionary (Ed., Brown, 1983, p. 3055), a steward is not only a "person entrusted with management of another's property" but also "a paid manager of a great house or estate."

And so it is in Malvolio's case: he manages Olivia's estate. What makes Malvolio the butt of the most famous trickery in all of Shakespeare's comedies is that he is not an honorable steward: he serves only himself. Olivia insightfully tells him:

O, you are sick of self-love, Malvolio, and taste with a distempered[14] appetite. (Arden Shakespeare, Ed., Lothian and Craik, p. 26)

Malvolio does not steal or misappropriate funds but he is officious in carrying out his duties and he lacks vision and actual ability: he is incapable of comprehending or adapting to what is changing in the world around him, believing himself to know all answers. He is easy to dupe because he regards himself as deserving and superior: he lacks honor.

Fooled by a letter written in Maria's handwriting but closely resembling the Countess Olivia's script, he believes at once that his beautiful and wealthy employer is in love 
with and wishes to marry him: oh, the allure of wealth and status! The letter ends with "go to, thou art made if thou desir'st to be so. If not, let me see thee a steward still, the fellow of servants, and not worthy to touch Fortune's fingers" (Arden Shakespeare, Ed., Lothian and Craik, p. 71).

The pun on fortune, indicating both profit and risk is deliberate and has resonated through the ages.

Malvolio fails dismally, is briefly incarcerated as a lunatic and is finally retrenched by Olivia, his dignity in tatters. Malvolio has neglected the manner in which resources entrusted to him should have been managed. Shakespeare remains fascinated by the link between human behavior, business and the economy and the experts who attempt to manage and account for balance. It is clear that Shakespeare endorses the punishment of delinquent individuals like this ridiculous steward. We are reminded of the statement in the PWC (2016) survey that "Action must be taken against corrupt officials: such actions may include dismissals, civil actions and warnings."

\section{Conclusion}

\section{1 "The merchant of Venice"}

Our final indication that Shakespeare was an accountant comes from the enigmatic play, "The merchant of Venice," the first performance recorded being at the Court of King James in 1605. The play defies clear categorization as it has elements of tragedy, comedy, love story and Classical epic; it is what Polonius defined as:

\section{[...] tragical-historical-comical [...] scene individable. (refer to Introduction)}

However, the dominant theme, even in the three love stories presented in this play, is money: usury, the Rialto[15], borrowing, foolishly lending, legal contracts to clarify who owes what to whom, and all against the extravagant backdrop of Venice at the height of her power as Queen of the Adriatic and trade[16].

Young Bassanio is bankrupt as usual and he acknowledges this in phrases like, "disabled my estate"; "great debts"; and "all the debts I owe" (Arden Shakespeare, Ed., Brown, 1961, p. 12). He asks his doting and very wealthy friend, the merchant Antonio, to lend him yet more money because there is a way for Bassanio to recover financially. His solution? A wife who has inherited a fortune and is beautiful: it is clear here that Bassanio is not an accountant because he obviously does not understand even basic interest rates or possible risk at all: he has disregarded his responsibility and yet feels entitled to Antonio taking risks for him. As a successful businessman, flattered by all, Antonio should know better: employ experts with "the highest standards of technical competency and ethics" (University of the Witwatersrand, School of Accountancy, SAKAI, 2017).

Antonio's capital is heavily invested in his ships carrying rich cargo from the Indies but poor cash flow does not stop him: he instructs Bassanio to "Try what my credit can in Venice do" (Arden Shakespeare, Ed., Brown, 1961, p. 180). Antonio's enterprises clearly form an entity so we are reminded of King's recommendation of conduct involving a stakeholder approach to management (King, Code III, 2002). Antonio defaults: his willingness to raise a loan in order to lend more money to Bassanio introduces the usurer, Shylock who, hating Antonio for past insults to his person and his Jewish religion, sees the chance for revenge through business and this leads to "the merry bond" (Arden Shakespeare, Ed., Brown, 1961, p. 29) becoming a legally binding contract, in spite of the macabre conditions set down in the loan statement. Shylock dictates the terms which must and will be notarized as he is a major stakeholder:

If you repay me not on such a day In such a place, such sum or sums as are Express'd in the condition, let the forfeit Be nominated for an equal pound Of your fair flesh. (Arden Shakespeare, Ed., Brown, 1961, pp. 29-30) 
AAAJ 31,8

Antonio, sure that his merchandise will return safely, arrogantly signs the contract, the money is raised by Shylock, and Bassanio continues to spend. We all know the old proverb that a fool and his money are soon parted: Antonio's ships are lost at sea, the three thousand ducats[17] cannot be paid by due date, Antonio is jailed and the matter goes to court. An expert would have avoided this:[18]

Shylock, his heart further hardened by his daughter stealing money and jewels before eloping with a Christian, rails against the Merchant:

There [in Antonio] I have another bad match, a bankrupt, a prodigal, who dare scarce show his head on the Rialto [...] let him look to his bond! (Arden Shakespeare, Ed., Brown, 1961, p. 72)[19]

As Shylock reels from the deception of his daughter and the theft of money and valuables, he draws comfort from Antonio's "ill luck" (Arden Shakespeare, Ed., Brown, 1961, p. 75). (After all, the notary is also a type of steward, curating property business deals and documents.) Antonio cannot escape death because the "merry bond" (Arden Shakespeare, Ed., Brown, 1961, p. 29) is legally ratified[20].

But Shakespeare the accountant, by means of the character Portia, the "lady richly left" (Arden Shakespeare, Ed., Brown, 1961, p. 13), now begins to weave the Bond plot into the second plot of finance and balances. Bassanio wins Portia by facing her deceased father's test: the man who chooses the casket in which Portia's portrait lies is the victor. Assets and money show their power here as the three caskets are made of three different metals gold, silver and lead, respectively.

Bassanio chooses the "base lead" (Arden Shakespeare, Ed., Brown, 1961, p. 65) and wins Portia's hand because she gives him a clue. Love's agility is not our subject but the power and fascination of money remain central: Portia, fully in charge from the start of the marriage, provides the three thousand ducats, lies to her new husband, hastens to Venice and, disguised as a lawyer and defeats Shylock in court. Her prejudice and cruelty are not our subject either but the Shakespeare accountant makes it clear that, even though Shylock is ruined, Bassanio will still "pay." This foolish and vain young man has not learned the most basic lesson: nothing is free and he is accountable, although not in this instance in crude monetary terms. Ethics is central here.

Shylock is awarded nothing, not even his principal, the original loan (Arden Shakespeare, Ed., Brown, 1961, p. 117). His property is forfeited and he leaves the court a beggar. But the law is also not our theme: the merchant, Antonio, emerges victorious as his ships, securing his wealth, return home.

Shakespeare's fascination with balances, losses, profits, financial astuteness or lack thereof, and accounting education abound in this popular play.

Shylock is a villain because he has valued human flesh in ducats; Antonio is a villain because, with the weight on Venetian law on his side, he sanctimoniously destroys his antagonist Shylock. But the author of this paper firmly iterates that accounting is the main character in this play. Processes and practice depend on the roles of those in charge, King's "ethical leaderships" concept (King, Code III, 2009).

\subsection{Final point}

The author has been aware, while reading toward and writing this paper, of the interesting interconnectness of many academic disciplines. The focus here is language proficiency, drama and accounting but many more themes exist. There is scope for exciting further research.

Note: All except one of the Shakespeare texts consulted in this paper are in the Arden Shakespeare series (see Section 2.1)

Lelys Maddock School of Accountancy, University of the Witwatersrand, Johannesburg, South Africa 


\section{Notes}

1. Desire (for wealth) is the root of all evil.

2. Greer (p. 201) refers to New Place in "the acquisition of a compromised title to a rambling house he spent little or no time in." (emphasis added).

3. Greer (p. 268) refers to Ann Shakespeare as "maltster and money-lender."

4. Duncan further rewards Lady Macbeth with a diamond: is this not a fine example of profit as opposed to loss, an attractive gift for a favorite warrior's wife, an incentive to remain loyal, risk management at its best?

5. Malcolm is heir to Duncan's throne.

6. "We may therefore regard Rome [as] the greatest founder of military colonies in ancient history" (Cary and Haarholf, 1966, p. 54). These colonies provided money, food and armies.

7. The mob is in a frenzy as they hear that Caesar has bequeathed "To every Roman citizen [...] seventy five drachmas" (p. 270) and "hath left you all his walks, His private arbours and new-planted orchards, on this side Tiber" (Arden Shakespeare, Dorsch, 1966, p. 87). The coup, of course, is that he has bequeathed this in perpetuity, that is, "forever."

8. The New Shorter Oxford Dictionary defines the Medieval and Renaissance term "cofferer" as "one who looks after the coffers," i.e. treasury, funds and these are accountants who balance inflow and outflow of moneys.

9. The Church possessed vast tracts of land and treasures of many kinds.

10. Those who paid taxes to the monarch and the nobles in peace, also became soldiers in times of war. They expected to be rewarded for loyal service (see Section 2.2).

11. For example, Duncan in "Macbeth" and King Hamlet in "Hamlet."

12. Elizabeth I, daughter of Henry and Anne Boleyn, the most powerful monarch in England's history.

13. A ducat was a gold coin of great value.

14. "distempered": diseased, unbalanced and rogue.

15. The Rialto is the (Renaissance) financial hub or stock exchange in Venice.

16. The very title of the play is proof of this: it is named for the merchant, Antonio. The currency of merchants remains trade today.

17. A ducat was gold coin of great value.

18. An auditor's function is to ensure that financial information is correct.

19. Business rescue and/or liquidation are a debate beyond the scope of this paper.

20. A notary is "a person publicly authorized to draw up or certify contracts, deeds, etc." (New Shorter Oxford, 1993).

\section{References}

Abbey Library (1969), “'Hamlet’ complete works of William Shakespeare”, Abbey Library, London, p. 885.

Bolt, R. (1985), “A man for all seasons”, Notes by Wood, E.R., Heinmann, London, p. 2.

Brooks, H.F. (Ed.) (1983), A Midsummer Night's Dream, (Arden Shakespeare), Methuen, London, pp. 5-8, 30, 35-36, 97.

Caesar, J. and Colbeck, C. (Eds) (1963), 'The Gallic Wars VI'/ 'De Bello Gallico', Macmillan and Co. Ltd, London, pp. 1-29.

Cary, M. and Haarhoof, T.J. (1966), "Life and thought in the Greek and Roman world", University Paperbacks, Methuen, London, p. 54, 79. 
Cassell's New Latin Dictionary (Ed.) (1966), Simpson, D.P., London, p. 492, 539.

De Lisle, L. (2013), “Tudors”, Vintage, London, p. 247.

Dorsch, T.S. (Ed.) (1966), Julius Caesar, (Arden Shakespeare), Methuen, London, pp. 7, 79-93.

Jenkins, H. (Ed.) (1982), Hamlet, (Arden Shakespeare), Methuen, London, pp. 41, 59, 204-206, 229-232, 237, 269-270, 414.

King, M. (2009), "King Code III”, LexisNexis, Durban.

Muir, K. (Ed.) (1989), Macbeth, (Arden Shakespeare), Routledge, London, p. 40, 66, 75, 162.

PWC (2016), "Economic Crime: a South African pandemic”, Retrieved, available at: www.pwc.co.za/en/ assets/pdf/south-african-crime-survery-2016.pdf (accessed 4 November 2017).

SAKAI (2017), "Auditing IV course outline notes", School of Accountancy, University of the Witwatersrand, E-learning platform, available at: www.cle.wits.ac.za (accessed November 2017).

Walter, J.H. (Ed.) (1985), King Henry V, (Arden Shakespeare), Methuen, London, pp. 12, 41, 57, 85, 107-109.

\section{Further reading}

Brown, J.R. (Ed.) (1981), The Merchant of Venice, (Arden Shakespeare), Metheun, London, pp. 29-30, 72, $75,65,117$.

Duffy, M. (1989), "The erotic life of faeries”, Cardinal, London, pp. 152-154.

Greer, G. (2007), "Shakespeare's wife”, Bloomsbury, p. 201, 268.

Lothian, J.M. and Craik, T.W. (Eds) (1978), Twelfth Night, (Arden Shakespeare), Methuen, London, p. $12,26,71$.

Oxford Concise English Dictionary (1964), Clarendon Press.

Zweig, P. (1980), "The Heresy of self-love”, Princeton University Press, p. 67. 